\title{
Pengaruh Empat Galur Bakteri Pemacu Pertumbuhan Tanaman dan Waktu Inokulasi Virus terhadap Keparahan Penyakit Daun Keriting Kuning Cabai
}

\author{
Effect of Four Isolates of Plant Growth-Promoting Rhizobacteria \\ and Virus Inoculation Time \\ on Intensity of Pepper Yellow Leaf Curl Disease
}

\author{
Hari Priwiratama ${ }^{1,2}$, Sri Hendrastuti Hidayat ${ }^{1 *}$, Widodo $^{1}$ \\ ${ }^{1}$ Institut Pertanian Bogor, Bogor 16680 \\ ${ }^{2}$ Pusat Penelitian Kelapa Sawit, Pematang Siantar 21100
}

\begin{abstract}
ABSTRAK
Bakteri perakaran pemacu pertumbuhan tanaman (plant growth promoting rhizobacteria, PGPR) telah menunjukkan keefektifan dalam menekan serangan patogen. Empat galur PGPR (Bacillus polymixa BG25, B. subtilis SB3, Pseudomonas fluorescens PG01, dan P. fluorescens ES32) serta campuran suspensi empat bakteri diaplikasikan melalui perendaman benih. Inokulasi Geminivirus dilakukan di rumah kaca pada 3, 5, dan 6 minggu setelah tanam dengan bantuan vektor Bemisia tabaci (Hemiptera: Aleyrodidae). Tanaman tanpa perlakuan perendaman benih dalam suspensi bakteri digunakan sebagai pembanding. Interaksi antara waktu inokulasi virus dan jenis bakteri yang digunakan tidak memberikan pengaruh yang nyata dalam menghambat masa inkubasi, tetapi berpengaruh nyata terhadap keparahan penyakit daun keriting kuning. Persentase keparahan penyakit rendah pada tanaman yang diinokulasi pada umur tanaman yang lanjut. Beberapa perlakuan bakteri berpengaruh terhadap tinggi tanaman, jumlah cabang, dan bunga.
\end{abstract}

Kata kunci: Bemisia tabaci, Geminivirus, pemacu pertumbuhan tanaman, PGPR

\begin{abstract}
Plant growth-promoting rhizobacteria (PGPR) has effectively reduced infection of pathogens. $B a-$ cillus polimixa $\mathrm{BG} 25$, B. subtilis SB3, Pseudomonas fluorescens PG01, P. fluorescens ES32, and their combinations were used as seed treatment. Bemisia tabaci (Hemiptera: Aleyrodidae) was used to inoculate Geminivirus at 3,5, and 6 weeks after planting. Seeds without any bacteria treatment were used as controlled plant. Treatment of PGPR and time of inoculation were significantly effect disease intensity, but not incubation period. Late infection of Geminivirus reduced disease intensity. Based on measurement of plant height, number of branch, and flowers it was concluded that some bacterial treatments was significantly effect plant growth.
\end{abstract}

Key words: Bemisia tabaci, Geminivirus, PGPR, plant growth promoting rhizobacteria

\footnotetext{
*Alamat penulis korespondensi: Departemen Proteksi Tanaman, Fakultas Pertanian, Institut Pertanian Bogor, Kampus Darmaga, Jalan Kamper, Bogor 16680 Tel: 0251- 8629364, Faks: 0251- 8629362, Surel: srihendrastutihidayat@gmail.com
} 


\section{PENDAHULUAN}

Penyakit daun keriting kuning yang disebabkan Geminivirus merupakan penyakit penting pada tanaman cabai di Indonesia. Penyakit ini mampu menyerang setiap tahap perkembangan tanaman cabai, sejak pesemaian hingga masa pembuahan. Serangan akan lebih merugikan jika terjadi pada fase vegetatif muda karena dapat menyebabkan penurunan kemampuan berbuah, sedangkan serangan pada fase generatif menyebabkan penurunan kualitas buah (Sulandari et al. 2006). Tanaman cabai yang terinfeksi Geminivirus akan menunjukkan gejala berupa penguningan disertai penggulungan daun, terutama pada daun muda.

Serangan Geminivirus juga menyebabkan penghambatan pertumbuhan tanaman dan penurunan hasil (Rusli et al. 1999). Ahmed et al. (2001) melaporkan bahwa di Sudan kehilangan hasil karena penyakit ini dapat mencapai $100 \%$, sedangkan di Gezira kehilangan hasil mencapai 70\%. Menurut laporan Direktorat Perlindungan Tanaman Hortikultura (Ditlintan Hortikultura), total kerugian pada tanaman cabai akibat penyakit ini mencapai lebih dari 20 milyar Rupiah pada tahun 2007, terbesar (lebih dari 5 milyar Rupiah) terjadi di Jawa Tengah (Sito 2011). Beberapa usaha pengendalian untuk mengurangi kejadian penyakit yang disebabkan oleh Geminivirus telah banyak diupayakan, termasuk perakitan varietas tahan dan pengelolaan serangga vektornya, yaitu $B$. tabaci. Upaya pencarian metode pengendalian yang efektif dan tepat masih tetap dilakukan mengingat laporan mengenai intensitas dan penyebaran penyakit kuning pada tanaman cabai terus meningkat.

Penggunaan bakteri perakaran pemacu pertumbuhan tanaman (plant growth promoting rhizobacteria, PGPR) mulai banyak dikembangkan sebagai salah satu upaya pengendalian penyakit tersebut di atas. Teknik pengendalian ini sering disebut bakterisasi, yaitu perlakuan benih atau akar perkecambahan dengan suspensi bakteri sehingga dapat memperbaiki pertumbuhan tanaman.
Pemanfaatan PGPR dalam pengendalian patogen telah banyak dilakukan, terutama terhadap cendawan dan bakteri (van Loon et al. 1998). Aplikasi PGPR untuk virus-virus penting penyebab penyakit diantaranya dilaporkan efektif menekan Cucumber mosaic virus (CMV), Tobacco mosaic virus (TMV), Tobacco necrosis virus (TNV), dan Tomato mottle virus (ToMoV) (Maurhofer et al. 1994; Raupach dan Kloepper 1998; Zehnder et al. 2000; Murphy et al. 2000). Pemanfaatannya dalam pengendalian penyakit daun keriting kuning pada tanaman cabai belum banyak diketahui. Oleh karena itu, penelitian dilakukan untuk mengetahui pengaruh penggunaan PGPR serta variasi waktu inokulasi virus terhadap perkembangan penyakit kuning pada tanaman cabai besar.

\section{BAHAN DAN METODE}

\section{Pembuatan Suspensi Bakteri}

Biakan murni B. polymixa BG25, B. subtilis SB3, P. fluorescens PG01, dan P. fluorescens ES32 diperoleh dari koleksi PGPR milik Klinik Tanaman, Departemen Proteksi Tanaman, Institut Pertanian Bogor. Koloni bakteri yang berasal dari media nutrient broth (NB) diremajakan pada media triptic soy agar (TSA untuk kelompok Bacillus) dan King's $B$ (untuk kelompok Pseudomonas) dengan menggoreskan masing-masing 1 lup suspensi pada media tersebut. Bakteri yang telah diremajakan diinkubasi pada suhu ruang selama 48 jam. Sebanyak 15 lup biakan murni yang diperoleh diencerkan dalam $100 \mathrm{~mL}$ $\mathrm{NaCl} 0.85 \%$ sehingga didapat suspensi bakteri (stok) dengan kepadatan masing-masing $10^{12} \mathrm{cfu} \mathrm{mL}^{-1}$ untuk Bacillus dan $10^{13} \mathrm{cfu} \mathrm{mL}^{-1}$ untuk Pseudomonas (Jamaliyah 2005).

\section{Perlakuan Benih dan Penanaman Tanaman Uji}

Masing-masing suspensi stok bakteri diencerkan secara bertingkat sehingga dida-

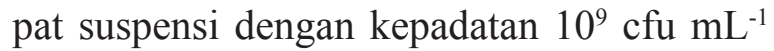
dalam $10 \mathrm{~mL} \mathrm{NaCl} 0.85 \%$. Sebanyak $2 \mathrm{~mL}$ dari masing-masing suspensi bakteri dicampur sehingga didapat suspensi kombinasi 
dari empat bakteri tersebut dengan kepadatan yang sama. Benih cabai yang sebelumnya telah dicuci kemudian dimasukkan ke dalam suspensi bakteri (BG25, SB3, PG01, ES32, dan campuran keempatnya) dan dibiarkan selama 10 jam pada suhu ruang. Sebagai kontrol, benih cabai direndam pada $8 \mathrm{~mL} \mathrm{NaCl}$ $0.85 \%$ selama 10 jam.

Benih yang telah direndam kemudian ditanam pada baki semai dengan media campuran tanah dan pupuk kandang dengan perbandingan 2:1 (v/v). Ketika tanaman berumur 4 minggu setelah tanam (MST) dilakukan pemindahan tanaman ke dalam kantong plastik $35 \mathrm{~cm} \times 35 \mathrm{~cm}$ yang berisi media yang sama dengan persemaian.

\section{Penularan dengan Serangga Vektor}

Imago B. tabaci dibiakkan pada tanaman kapas yang berumur 2 minggu dalam kurungan kedap serangga ( $1 \mathrm{~m} \times 1 \mathrm{~m} \times 1 \mathrm{~m})$. Serangga dibiarkan berkembang biak hingga jumlahnya mencukupi untuk inokulasi virus. B. tabaci yang bebas virus diinfestasikan pada tanaman tomat yang terinfeksi Geminivirus isolat Segunung dan dibiarkan selama 24 jam melewati periode makan akuisisi. Serangga kemudian dipindahkan ke tanaman cabai sehat yang berumur 5 minggu setelah tanam (MST) dan tanaman diinkubasi hingga menunjukkan gejala penyakit kuning.

Inokulasi virus dilakukan pada kurungan inokulasi ( $1 \mathrm{~m} \times 1 \mathrm{~m} \times 2 \mathrm{~m})$ saat tanaman telah menunjukkan daun sejati, yaitu pada saat 3, 5, dan 6 MST. Serangga vektor dan sumber inokulum yang telah ada dimasukkan ke dalam kurungan. Setelah 3 hari, tanaman yang akan diinokulasi dimasukkan ke dalam kurungan tersebut. Selama periode itu, tanaman uji dan sumber inokulum diberi gangguan fisik untuk memastikan vektor hinggap dan makan (inokulasi) pada setiap tanaman uji. Metode ini dilakukan khususnya untuk tanaman yang berumur 3 dan 5 MST, sedangkan untuk tanaman yang berumur 6 MST inokulasi dilakukan secara langsung dengan menaruh sumber inokulum dan sejumlah vektor di antara tanaman yang akan diuji selama 3 hari.

\section{Pengukuran Keparahan Penyakit}

Pengukuran keparahan penyakit mulai dilakukan pada saat 3 minggu setelah periode makan inokulasi (MSI) dengan mengukur skor penyakit pada masing-masing tanaman uji. Kategori skor yang dipakai ialah: 0 , tidak bergejala; 1, penguningan tulang daun; 2 , seluruh tulang daun menguning dan daun mengeriting; 3, lamina daun menguning dan daun mengeriting; 4, tanaman kerdil, seluruh daun menguning, reduksi ukuran daun, dan daun mengeriting seluruhnya.

Nilai skor yang didapat dikonversi menjadi nilai keparahan penyakit berdasarkan rumus Townsend dan Heüberger (Agrios 1997).

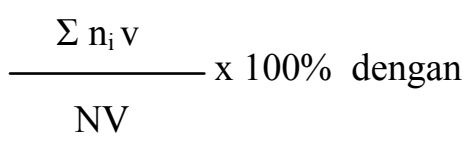

$\mathrm{n}_{\mathrm{i}}$, jumlah tanaman pada skor ke-i; vi, nilai skor penyakit; $\mathrm{N}$, jumlah tanaman yang diamati; V, skor tertinggi.

Peubah lainnya ialah masa inkubasi yang diamati sejak periode makan inokulasi berakhir hingga munculnya gejala awal dari penyakit tersebut.

\section{Pengamatan Pertumbuhan Tanaman}

Pengukuran tinggi tanaman, jumlah cabang (sekunder), jumlah daun, dan jumlah bunga pertama dilakukan pada saat tanaman mencapai masa pembungaan 15 MST.

\section{Rancangan Percobaan dan Analisis Data}

Percobaan disusun dalam rancangan acak faktorial dengan dua faktor utama, yaitu jenis bakteri dan waktu inokulasi virus. Perlakuan jenis bakteri terdiri atas 6 taraf galur bakteri (BG25, SB3, PG01, ES32, kombinasi empat galur bakteri, dan pembanding). Perlakuan waktu inokulasi terdiri atas 3 taraf umur tanaman saat diinokulasi (3, 5, dan 6 MST). Unit perlakuan disusun dalam 4 blok dengan 3 unit tanaman contoh pada masing-masing blok. 


\section{HASIL}

\section{Masa Inkubasi Penyakit}

Berdasarkan analisis statistik dapat disimpulkan bahwa interaksi antara waktu inokulasi virus dan jenis bakteri yang digunakan tidak memberikan pengaruh yang nyata dalam menghambat waktu pemunculan gejala awal (masa inkubasi) penyakit daun keriting kuning. Perlakuan bakteri yang diberikan tidak mempengaruhi masa inkubasi penyakit, baik pada waktu inokulasi yang sama maupun antara waktu inokulasi yang berbeda. Waktu kemunculan gejala tanaman yang diinokulasi melalui serangga vektor pada 3, 5, dan 6 MST berturut-turut 8.93, 9.29, dan 9.36 hari. Walaupun demikian, tanaman yang diberi perlakuan bakteri B. subtilis SB3, $P$. fluorescens PG01, dan ES32 menunjukkan masa inkubasi yang lebih lama dibandingkan dengan tanaman yang tidak diberi perlakuan bakteri (Tabel 1).

\section{Perkembangan Keparahan Penyakit}

Interaksi antara waktu inokulasi virus dan jenis bakteri yang digunakan memberikan pengaruh yang nyata terhadap keparahan penyakit daun keriting kuning (Tabel 2). Semakin lama tanaman terinfeksi virus (taraf waktu inokulasi semakin tinggi) maka tingkat keparahan penyakit pada tiap perlakuan semakin rendah. Pengamatan yang dilakukan sejak tanaman berusia 3 - 9 MSI

Tabel 1 Masa inkubasi penyakit daun keriting kuning cabai pada tanaman dengan perlakuan bakteri pemacu pertumbuhan tanaman

\begin{tabular}{ll}
\hline Perlakuan bakteri & $\begin{array}{l}\text { Masa } \\
\text { inkubasi } \\
\text { (hari) }\end{array}$ \\
\hline Tanpa bakteri & $8.14 \mathrm{~b}^{*}$ \\
Bacillus polymixa BG25 & $9.28 \mathrm{ab}$ \\
B. subtilis SB3 & $9.30 \mathrm{a}$ \\
Pseudomonas fluorescens PG01 & $9.69 \mathrm{a}$ \\
P. fluorescens ES 32 & $9.61 \mathrm{a}$ \\
Campuran 4 bakteri & $9.14 \mathrm{ab}$ \\
\hline
\end{tabular}

*Angka yang diikuti huruf yang sama tidak berbeda nyata pada $\alpha 0.05$ menunjukkan kecenderungan yang sama ketika terjadi penurunan tingkat keparahan penyakit daun keriting kuning. Pada 7 MSI beberapa perlakuan bakteri menunjukkan tingkatkeparahan penyakit yang lebih tinggi pada taraf waktu inokulasi 5 MST, tetapi keparahannya kembali menjadi rendah ketika memasuki 8 MSI.

Peningkatan toleransi tanaman pada taraf waktu inokulasi yang lebih tinggi dapat dilihat pada 7 - 9 MSI. Secara umum terdapat perbedaan yang nyata antara perlakuan pada taraf waktu inokulasi yang lebih rendah (3 MST) dan lebih tinggi (6 MST). Perbedaan nyata pada saat 7 dan 8 MSI pada beberapa perlakuan bakteri (tidak terjadi pada perlakuan tanpa bakteri) dengan taraf waktu inokulasi 3 dan 6 MST menunjukkan bahwa perlakuan bakteri akan efektif menekan tingkat keparahan penyakit dengan syarat tanaman tidak terinfeksi pada awal perkembangan tanaman (3 MSI), melainkan baru terinfeksi saat tanaman sudah berkembang dengan baik (6 MST).

\section{Perkembangan Tinggi Tanaman, Jumlah Cabang, Daun, dan Bunga}

Terdapat interaksi antara waktu inokulasi dan aplikasi bakteri terhadap pertumbuhan tanaman (Tabel 3). Secara umum tidak terdapat perbedaan tinggi tanaman yang nyata antara perlakuan jenis bakteri pada taraf waktu inokulasi yang berbeda.

Walaupun demikian, perlakuan P. fluorescens ES32 pada waktu inokulasi 6 MST menyebabkan perbedaan yang nyata terhadap tinggi tanaman dibandingkan dengan tanpa perlakuan bakteri. Hal ini menunjukkan bahwa P. fluorescens ES32 mampu meningkatkan pertumbuhan tanaman jika Geminivirus baru menginfeksi tanaman pada umur 6 MST. Tidak ada perbedaan yang nyata untuk interaksi perlakuan jenis bakteri dengan waktu inokulasi terhadap jumlah cabang, kecuali perlakuan $P$. fluorescens ES32 pada 6 MST. Tidak ada perbedaan nyata untuk semua kombinasi perlakuan terhadap jumlah daun, tetapi terdapat perbedaan yang nyata terhadap jumlah bunga. Jumlah bunga lebih tinggi untuk 
Tabel 2 Pengaruh interaksi perlakuan jenis bakteri dan waktu inokulasi virus terhadap perkembangan keparahan penyakit

\begin{tabular}{|c|c|c|c|c|c|c|}
\hline \multirow{2}{*}{ Perlakuan } & \multicolumn{6}{|c|}{ Keparahan penyakit pada masa setelah inokulasi } \\
\hline & 4 & 5 & 6 & 7 & 8 & 9 \\
\hline \multicolumn{7}{|c|}{3 minggu setelah tanam } \\
\hline Tanpa bakteri & $58.33 \mathrm{c}$ & $64.58 \mathrm{a}$ & $68.75 \mathrm{abc}$ & $75.00 \mathrm{c}$ & $68.75 \mathrm{abc}$ & $75.00 \mathrm{c}$ \\
\hline BG25 & $52.08 \mathrm{bc}$ & $58.33 \mathrm{a}$ & $66.67 \mathrm{abc}$ & $75.00 \mathrm{c}$ & $66.67 \mathrm{abc}$ & $75.00 \mathrm{c}$ \\
\hline SB3 & $47.92 \mathrm{abc}$ & $58.33 \mathrm{a}$ & $66.67 \mathrm{abc}$ & $72.92 \mathrm{c}$ & $66.67 \mathrm{abc}$ & $75.00 \mathrm{c}$ \\
\hline PG01 & $45.83 \mathrm{abc}$ & $62.50 \mathrm{a}$ & $70.83 \mathrm{abc}$ & $72.92 \mathrm{c}$ & $70.83 \mathrm{abc}$ & $75.00 \mathrm{c}$ \\
\hline ES32 & $37.50 \mathrm{ab}$ & $58.33 \mathrm{a}$ & $66.66 \mathrm{abc}$ & $75.00 \mathrm{c}$ & $66.66 \mathrm{abc}$ & $75.00 \mathrm{c}$ \\
\hline Campuran & $43.75 \mathrm{abc}$ & $66.67 \mathrm{a}$ & $68.75 \mathrm{abc}$ & $72.92 \mathrm{c}$ & $68.75 \mathrm{abc}$ & $75.00 \mathrm{c}$ \\
\hline \multicolumn{7}{|c|}{5 minggu setelah tanam } \\
\hline Tanpa bakteri & $52.08 \mathrm{bc}$ & $64.58 \mathrm{a}$ & $72.92 \mathrm{bc}$ & $75.00 \mathrm{c}$ & $68.75 \mathrm{c}$ & $68.75 \mathrm{bc}$ \\
\hline BG25 & $35.42 \mathrm{ab}$ & $50.00 \mathrm{a}$ & $62.50 \mathrm{abc}$ & $75.00 \mathrm{c}$ & $70.83 \mathrm{c}$ & $64.58 \mathrm{abc}$ \\
\hline SB3 & $45.83 \mathrm{abc}$ & $60.42 \mathrm{a}$ & $70.83 \mathrm{abc}$ & $75.00 \mathrm{c}$ & $66.67 \mathrm{bc}$ & $62.49 \mathrm{abc}$ \\
\hline PG01 & $35.42 \mathrm{ab}$ & $56.25 \mathrm{a}$ & $66.67 \mathrm{abc}$ & $75.00 \mathrm{c}$ & $68.75 \mathrm{c}$ & $62.50 \mathrm{abc}$ \\
\hline ES32 & $43.75 \mathrm{abc}$ & $60.42 \mathrm{a}$ & $64.58 \mathrm{abc}$ & $75.00 \mathrm{c}$ & $70.83 \mathrm{c}$ & $68.75 \mathrm{bc}$ \\
\hline Campuran & $47.92 \mathrm{abc}$ & $58.33 \mathrm{a}$ & $75.00 \mathrm{c}$ & $75.00 \mathrm{c}$ & $66.67 \mathrm{bc}$ & $60.41 \mathrm{ab}$ \\
\hline \multicolumn{7}{|c|}{6 minggu setelah tanam } \\
\hline Tanpa bakteri & $47.92 \mathrm{abc}$ & $64.58 \mathrm{a}$ & $66.67 \mathrm{abc}$ & $68.75 \mathrm{bc}$ & $68.75 \mathrm{bc}$ & $58.33 \mathrm{ab}$ \\
\hline BG25 & $37.50 \mathrm{ab}$ & $56.25 \mathrm{a}$ & $56.25 \mathrm{ab}$ & $60.41 \mathrm{ab}$ & $56.25 \mathrm{ab}$ & $54.16 \mathrm{a}$ \\
\hline SB3 & $33.33 \mathrm{ab}$ & $50.00 \mathrm{a}$ & $54.16 \mathrm{a}$ & $56.25 \mathrm{a}$ & $58.33 \mathrm{abc}$ & $56.25 \mathrm{ab}$ \\
\hline PG01 & $35.42 \mathrm{ab}$ & $54.16 \mathrm{a}$ & $54.16 \mathrm{a}$ & $58.33 \mathrm{a}$ & $56.25 \mathrm{ab}$ & $58.33 \mathrm{ab}$ \\
\hline ES32 & $31.25 \mathrm{a}$ & $52.08 \mathrm{a}$ & $54.16 \mathrm{a}$ & $58.33 \mathrm{a}$ & $54.16 \mathrm{a}$ & $54.16 \mathrm{a}$ \\
\hline Campuran & $33.33 \mathrm{ab}$ & $56.25 \mathrm{a}$ & $58.33 \mathrm{abc}$ & $58.33 \mathrm{a}$ & $56.25 \mathrm{ab}$ & $60.41 \mathrm{ab}$ \\
\hline
\end{tabular}

BG25, B. polymixa BG25; SB3, B. subtilis SB3; PG01, P. fluorescens PG01; ES32, P. fluorescens ES32; Campuran, campuran 4 jenis bakteri.

*Angka yang diikuti dengan huruf yang sama dalam satu kolom tidak berbeda nyata pada $\alpha 0.05$

tanaman yang diberi perlakuan bakteri $P$. fluorescens PG01 dan ES32 pada waktu inokulasi 3 MST dibandingkan dengan tanaman tanpa perlakuan bakteri. Sebaliknya, jumlah bunga lebih rendah untuk tanaman yang diberi perlakuan bakteri B. subtilis SB3 dibandingkan dengan tanaman tanpa perlakuan bakteri.

\section{PEMBAHASAN}

Penyakit daun keriting kuning yang disebabkan oleh anggota kelompok Geminivirus merupakan salah satu penyakit penting pada tanaman cabai yang sudah menyebar ke berbagai sentra produksi cabai di Indonesia (Sulandari et al. 2006; Hidayat et al.
2006; Trisno et al. 2009). Berbagai upaya pengendalian untuk menekan penyakit tersebut telah banyak dilakukan tetapi belum banyak memberikan hasil yang memuaskan. Geminivirus merupakan virus yang sulit untuk dikendalikan karena memiliki tanaman inang yang luas, termasuk beberapa spesies gulma (Meliansyah et al. 2011), dan kemampuannya ditularkan oleh serangga vektor, kutu-kebul B. tabaci, yang merupakan serangga polifag (Hendrival et al. 2011). Pengembangan varietas cabai tahan penyakit daun keriting kuning mengalami kendala karena sumber ketahanan terhadap Geminivirus pada plasma nutfah cabai belum teridentifikasi. 
Tabel 3 Pengaruh interaksi waktu inokulasi virus dengan perlakuan jenis bakteri terhadap tinggi tanaman, jumlah cabang sekunder, daun, dan bunga

\begin{tabular}{|c|c|c|c|c|}
\hline \multirow{2}{*}{ Perlakuan } & \multicolumn{4}{|c|}{ Pertumbuhan tanaman pada 15 minggu setelah tanam } \\
\hline & \multicolumn{4}{|c|}{ Tinggi tanaman } \\
\hline \multicolumn{5}{|c|}{3 minggu setelah tanam } \\
\hline Tanpa bakteri & $53.97 \mathrm{abc}$ & $35.08 \mathrm{ab}$ & $263.99 \mathrm{a}$ & $113.58 \mathrm{ab}$ \\
\hline BG25 & $48.01 \mathrm{ab}$ & $45.50 \mathrm{abc}$ & $315.00 \mathrm{a}$ & $169.83 \mathrm{~cd}$ \\
\hline SB3 & $47.06 \mathrm{ab}$ & $45.50 \mathrm{abc}$ & $373.84 \mathrm{a}$ & $100.92 \mathrm{a}$ \\
\hline PG01 & $49.22 \mathrm{abc}$ & $45.17 \mathrm{abc}$ & $294.42 \mathrm{a}$ & $174.08 \mathrm{~d}$ \\
\hline ES32 & $55.63 \mathrm{bc}$ & $50.92 \mathrm{bc}$ & $308.25 \mathrm{a}$ & $173.83 \mathrm{~d}$ \\
\hline Campuran & $53.97 \mathrm{abc}$ & $44.59 \mathrm{abc}$ & $242.09 \mathrm{a}$ & $139.42 \mathrm{abcd}$ \\
\hline \multicolumn{5}{|c|}{5 minggu setelah tanam } \\
\hline Tanpa bakteri & $54.28 \mathrm{abc}$ & $36.67 \mathrm{abc}$ & $378.92 \mathrm{a}$ & $140.42 \mathrm{abcd}$ \\
\hline $\mathrm{BG} 25$ & $57.10 \mathrm{bc}$ & $43.50 \mathrm{abc}$ & $303.42 \mathrm{a}$ & $169.67 \mathrm{~cd}$ \\
\hline SB3 & $55.36 \mathrm{abc}$ & $43.58 \mathrm{abc}$ & $237.67 \mathrm{a}$ & $118.17 \mathrm{abc}$ \\
\hline PG01 & $56.28 \mathrm{bc}$ & $42.25 \mathrm{abc}$ & $327.17 \mathrm{a}$ & $132.00 \mathrm{abcd}$ \\
\hline ES32 & $54.83 \mathrm{abc}$ & $36.58 \mathrm{abc}$ & $237.92 \mathrm{a}$ & $108.58 \mathrm{a}$ \\
\hline Campuran & $57.73 \mathrm{bc}$ & $33.50 \mathrm{a}$ & $269.84 \mathrm{a}$ & $117.00 \mathrm{abc}$ \\
\hline \multicolumn{5}{|c|}{6 minggu setelah tanam } \\
\hline Tanpa bakteri & $47.38 \mathrm{ab}$ & $39.00 \mathrm{abc}$ & $257.92 \mathrm{a}$ & $127.17 \mathrm{abcd}$ \\
\hline BG25 & $54.51 \mathrm{abc}$ & $37.83 \mathrm{abc}$ & $235.00 \mathrm{a}$ & $125.75 \mathrm{abcd}$ \\
\hline SB3 & $42.99 \mathrm{a}$ & $46.08 \mathrm{abc}$ & $305.25 \mathrm{a}$ & $149.50 \mathrm{abcd}$ \\
\hline PG01 & $55.16 \mathrm{abc}$ & $50.17 \mathrm{abc}$ & $314.92 \mathrm{a}$ & $169.17 \mathrm{~cd}$ \\
\hline ES32 & $61.36 \mathrm{c}$ & $53.34 \mathrm{c}$ & $284.92 \mathrm{a}$ & $165.92 \mathrm{bcd}$ \\
\hline Campuran & $49.44 \mathrm{abc}$ & $48.75 \mathrm{abc}$ & $322.25 \mathrm{a}$ & $139.08 \mathrm{abcd}$ \\
\hline
\end{tabular}

BG25, B. polymixa BG25; SB3, B. subtilis SB3; PG01, P. fluorescens PG01; ES32, P. fluorescens ES32; Campuran, campuran 4 jenis bakteri.

*Angka yang diikuti huruf yang sama dalam satu kolom tidak berbeda nyata pada $\alpha 0.05$

Strategi induksi ketahanan tanaman merupakan salah satu cara alternatif untuk menanggulangi penyakit tersebut. Penggunaan mikroorganisme nonpatogen dilaporkan dapat menginduksi ketahanan sistemik tanaman. Mann (1969) berhasil menekan infeksi TMV melalui aplikasi ekstrak B. uniflagellatus pada akar tembakau. Demikian pula Maurhofer et al. (1994) melaporkan kemampuan $P$. fluorescens yang mengolonisasi akar tembakau dalam menekan infeksi TNV. Aplikasi PGPR untuk mengendalikan Geminivirus dilaporkan oleh Murphy et al. (2000) menggunakan B. amyloliquefaciens 937a, B. subtilis 937b, dan B. pumilus SE34 untuk ToMoV. Hasil penelitian terdahulu tersebut memberikan indikasi potensi PGPR dalam menekan infeksi virus walaupun keberhasilan aplikasi PGPR sangat ditentukan oleh beberapa faktor di antaranya cara aplikasi, dan spesies tanaman inang.

Perlakuan $B$. polymixa BG25, B. subtilis SB3, P. fluorescens PG01, dan P. fluorescens ES32 melalui perendaman benih tidak dapat menekan perkembangan penyakit daun keriting kuning cabai secara nyata, walaupun keparahan penyakit cenderung lebih rendah pada tanaman yang diberi perlakuan bakteri dibandingkan dengan tanaman tanpa perlakuan bakteri. Perlakuan bakteri mampu menekan penyakit pada awal masa pertumbuhan tanaman, terutama P. fluorescens PG01 
dan ES32. Setelah 7 MST, semua perlakuan bakteri menunjukkan tingkat keparahan penyakit yang tidak berbeda nyata dengan perlakuan kontrol. Pertumbuhan tanaman tidak terlalu dipengaruhi oleh perlakuan bakteri pada waktu inokulasi yang berbeda. Tidak semua kombinasi dua faktor perlakuan tersebut menunjukkan pengaruh yang nyata terhadap pertumbuhan tanaman. Keefektifan PGPR tampaknya perlu ditingkatkan misalnya dengan memperbaiki formulasi dan cara aplikasi bakteri. Ryu et al. (1999) menggunakan formulasi LS213, yang terdiri atas campuran $B$. subtilis GB03 sebagai agens penginduksi pertumbuhan, B. amyloliquefaciens IN937 sebagai agens penginduksi ketahanan, dan $2.5 \%$ kitosan sebagai pembawa (carrier), untuk mengendalikan CMV. Formulasi LS213 yang dicampurkan pada media semai tomat ternyata mampu meningkatkan pertumbuhan tanaman dan menekan perkembangan gejala CMV.

Aplikasi PGPR sebagai salah satu komponen pengendalian penyakit daun keriting kuning cabai perlu dievaluasi lebih lanjut. Eksplorasi galur-galur bakteri rizosfer, pembuatan formulasi bakteri, dan cara aplikasi yang tepat sangat diperlukan untuk meningkatkan potensi PGPR dalam penekanan penyakit daun keriting kuning cabai.

\section{UCAPAN TERIMA KASIH}

Penelitian ini merupakan bagian dari penelitian yang dibiayai Program Hibah Kompetisi Program B, Departemen Proteksi Tanaman. Penulis mengucapkan terima kasih atas dukungan dananya.

\section{DAFTAR PUSTAKA}

Agrios GN. 1997. Plant Pathology. Ed ke-4. San Diego (US): Academic Pr.

Ahmed NE, Kanan HO, Sugimoto Y, Ma YQ, Inanaga S. 2001. Effect of imidacloprid on incidence of tomato yellow leaf curl virus. Plant Dis. 85(1):84-87. DOI: http://dx.doi. org/10.1094/PDIS.2001.85.1.84.
Hendrival, Hidayat P, Nurmansyah A. 2011. Kisaran inang dan dinamika populasi $\mathrm{Be}$ misia tabaci (Gennadius) (Hemiptera: Aleyrodidae) di pertanaman cabai merah. J HPT Tropika. 11(1):47-56.

Hidayat SH, Chatchawankanpanich O, Rusli E, Aidawati N. 2006. Begomovirus associated with pepper yellow leaf curl disease in West Java, Indonesia. J Mikrobiol Indones. 11(2): 87-89.

Jamaliyah W. 2005. Ketahanan hidup dan kemampuan antagonisme Bacillus subtilis ERB21, dan Pseudomonas flourescens ES32 dalam berbagai formulasi [skripsi]. Bogor (ID): Institut Pertanian Bogor.

Mann EW. 1969. Inhibition of tobacco mosaic virus by a bacterial extract. Phytopathology. 59(5):658-662.

Maurhofer M, Hase C, Meuwly P, Metraux JP, Defago G. 1994. Induction of systemic resistance of tobacco to tobacco necrosis virus by the root-colonizing Pseudomonas fluorescens strain CHA0: influence of the gacA gene and pyoverdine production. Phytopathology. 84(2):139-146. DOI: http://dx.doi.org/10.1094/Phyto-84-139.

Meliansyah R, Hidayat SH, Mutaqin KH. 2011. Geminiviruses associated with the weed species Ageratum conyzoides, Centipeda minima, Porophyllum ruderale, and Spilan-thes iabadicensis from Java, Indonesia. Microbiol Indones. 5(3):120-124. DOI: http://dx.doi.org/10.5454/mi.5.3.4.

Murphy JF, Zehnder GW, Schuster DJ, Sikora EJ, Polston JE, Kloepper JW. 2000. Plant growth-promoting rhizobacterial mediated protection in tomato against tomato mottle virus. Plant Dis. 84(7):779784. DOI: http://dx.doi.org/10.1094/ PDIS.2000.84.7.779.

Raupach GS, Kloepper JW. 1998. Mixture of plant growth-promoting rhizobacteria enhance biological control of multiple cucumber pathogens. Phytopathology. 88(11):1158-1164. DOI: http://dx.doi. org/10.1094/PHYTO.1998.88.11.1158.

Rusli ES, Hidayat SH, Suseno R, Tjahjono B. 1999. Geminivirus pada tanaman cabai: Variasi gejala dan kajian penularan. Bul 
Hama Penyakit Tumb. 11(1):126-131.

Ryu CM, Reddy MS, Zhang S, Murphy JF, Kloepper JW. 1999. Plant growth promotion of tomato by a biological preparation (LS213) and evaluation for protection against Cucumber mosaic virus. Phytopathology. 89(S6):S67.

Sito J. 2011. Pengendalian Geminivirus dalam upaya peningkatan produksi cabai. http:// penyuluhthl.wordpress.com/. [diakses 19 Jan 2012].

Sulandari S, Suseno R, Hidayat SH, Harjosudarmo J, Sosromarsono S. 2006. Deteksi dan kajian kisaran inang penyebab penyakit daun kriting kuning cabai. Hayati. 13(1):1-6.

Trisno J, Hidayat SH, Habazar T, Manti I, Jamsari. 2009. Detection and sequence diversity of Begomovirus associated with Yellow Leaf Curl Diseases of Pepper (Capsicum annuum) in West Sumatra, Indonesia. Microbiol Indones. 3(2):61-66. DOI: http://dx.doi.org/10.5454/mi.3.2.2.

Van Loon LC, Bakker PAHM, Pietersen CMJ. 1998. Systemic resistance induced by rhizosphere bacteria. Annu Rev Phytopathol. 36(1):453-83. DOI: http://dx.doi. org/10.1146/annurev.phyto.36.1.453.

Zehnder GW, Yao C, Murphy JF, Sikora ER, Kloepper JW. 2000. Induction of resistance in tomato against Cucumber mosaic cucumovirus by plant growth-promoting rhizobacteria. Biol Cont. 45(1):127-137. 